University of Pennsylvania Carey Law School

Penn Law: Legal Scholarship Repository

Faculty Scholarship at Penn Law

1999

\title{
The Scope of Private Securities Litigation: In Search of Liability Standards for Secondary Defendants
}

\author{
Jill E. Fisch \\ University of Pennsylvania Carey Law School
}

Follow this and additional works at: https://scholarship.law.upenn.edu/faculty_scholarship

Part of the Banking and Finance Law Commons, Business Law, Public Responsibility, and Ethics Commons, Business Organizations Law Commons, Courts Commons, Economic Policy Commons, Economics Commons, Law and Economics Commons, Securities Law Commons, and the Work, Economy and Organizations Commons

\section{Repository Citation}

Fisch, Jill E., "The Scope of Private Securities Litigation: In Search of Liability Standards for Secondary Defendants" (1999). Faculty Scholarship at Penn Law. 1218.

https://scholarship.law.upenn.edu/faculty_scholarship/1218

This Article is brought to you for free and open access by Penn Law: Legal Scholarship Repository. It has been accepted for inclusion in Faculty Scholarship at Penn Law by an authorized administrator of Penn Law: Legal Scholarship Repository. For more information, please contact PennlawIR@law.upenn.edu. 


\title{
THE SCOPE OF PRIVATE SECURITIES LITIGATION: IN SEARCH OF LIABILITY STANDARDS FOR SECONDARY DEFENDANTS
}

\author{
Jill E. Fisch*
}

\begin{abstract}
Recent federal court decisions have struggled to apply the Supreme Court's decision in Central Bank v. First Interstate to determine when outside professionals should be held liable as primary violators under section 10(b) of the Securities Exchange Act. In keeping with the Court's current interpretive methodology, Central Bank and its progeny employ a textualist approach. In this Article, Professor Fisch argues that literal textualism is an inappropriate approach for interpreting the federal securities laws generally and misguided in light of legislative developments post-dating the Central Bank decision. Instead, Professor Fisch advocates an approach that weighs Congress's recent endorsement of liability for outside professionals against the potential for litigation abuses perceived by the Central Bank Court. The Article concludes that recent federal decisions have been unduly restrictive in their interpretation of section 10(b) liability, and suggests that courts give greater consideration to the nature of the professional-client relationship and the role of liability in furthering the integrity of the securities markets.
\end{abstract}

\section{INTRODUCTION}

Twenty-five years ago, at the urging of then-SEC Chairman William Cary, the Supreme Court recognized an implied private right of action for federal proxy fraud in J.l. Case v. Borak. ${ }^{1}$ Under Cary's direction, the SEC advocated a broad remedial interpretation of the federal securities laws and an activist role for the courts in implementing the legislationan approach that reached fruition in Borak. More recently the federal courts have retreated from the activism espoused by Cary in favor of a textualist approach. Decisions such as Central Bank v. First Interstate ${ }^{2}$ relegate the legacy of William Cary to an almost forgotten era in which the federal judiciary was viewed as capable of weighing policy considerations, evaluating the recommendations of an expert administrative agency, ascertaining the regulatory objectives of a statutory scheme, and, ultimately, utilizing these factors to structure legal rules. ${ }^{3}$

There are reasons to question the value of textualism in interpreting the federal securities laws, however. In particular, a strict textual reading of the securities laws may frustrate the regulatory balance Congress cre-

* Professor of Law, Fordham Law School. I am grateful to Steve Thel and my mother for helpful comments on an earlier draft.

1. 377 U.S. 426 (1964)

2. 511 U.S. 164 (1994)

3. See, e.g., Richard H. Fallon, Jr. et al., Hart \& Wechsler's The Federal Courts and the Federal System 839 (4th ed. 1996) (describing Borak as the "high-water mark of judicial implication of remedies"). 
ated by promulgating the Private Securities Litigation Reform Act of 1995 and the Securities Litigation Uniform Standards Act of 1998. More broadly, these two statutes suggest a need to revisit Cary's conception of the judicial role in section $10(\mathrm{~b})^{4}$ lawmaking.

In Central Bank, the Court concluded that section 10 (b) does not permit liability to be imposed for aiding and abetting federal securities fraud, but it left open the potential scope of primary liability for secondary defendants. ${ }^{5}$ The Court offered no guidance as to the appropriate circumstances for the imposition of primary liability; it merely observed, in a somewhat cryptic statement, that secondary defendants, such as accountants, lawyers, and banks, could, under certain circumstances, be held liable as primary violators. ${ }^{6}$

Traditionally the federal courts have played a substantial role in crafting the scope of liability under the federal securities laws. This tradition continues as the courts struggle to apply the Supreme Court's decision in Central Bank in an effort to determine the liability exposure of outside professionals 7 in private securities fraud litigation under section 10 (b) of the Securities Exchange Act of $1934^{8}$ (the Exchange Act) and SEC Rule 10b-5. ${ }^{9}$ Two recent decisions illustrate the problems that courts face in interpreting the language of Central Bank.

In Klein v. Boyd, a panel of the Third Circuit held that a securities lawyer who significantly participates in the preparation of client disclosure documents can thereby become an author of the documents. ${ }^{10}$ If

4. Securities Exchange Act of 1934 § 10 (b), 15 U.S.C. § 78(b) (1994).

5. See Central Bank, 511 U.S. at 177 (1994).

6. See id. at 191 ("The absence of $\S 10$ (b) aiding and abetting liability does not mean that secondary actors in the securities markets are always free from liability under the securities Acts. Any person or entity, including a lawyer, accountant, or bank, who employs a manipulative device or makes a material misstatement (or omission) on which a purchaser or seller of securities relies may be liable as a primary violator under 10b-5, assuming all of the requirements for primary liability under Rule 10b-5 are met.").

7. This Article will only address the liability of outside professionals or secondary defendants. Cf. Mishkin v. Ageloff, No. 97 Civ. 2690 LAP, 1998 WL 651065 (S.D.N.Y. Sept. 23, 1998), slip op. at $17 \mathrm{n} .12$ (suggesting that the scope of primary liability for secondary actors may differ from that applicable to principals). For the purposes of this Article, secondary defendants include attorneys, accountants, banks, investment banks, and other professionals who render services in connection with securities disclosure. Some courts and commentators have sought to distinguish between these professionals in formulating liability standards based upon the nature of the services performed. See, e.g., Lewis D. Lowenfels \& Alan R. Bromberg, Liabilities of Lawyers and Accountants Under Rule 10b-5, 53 Bus. Law. 1157 (1998) (describing developing patterns of liability standards imposed in cases involving accountants and those involving lawyers). This Article will not address the question of whether courts should develop different standards for different types of professionals.

8. 15 U.S.C. $\S 78$ (b) (1994).

9. 17 C.F.R. § $240.10 b-5$ (1998).

10. [1997-1998 Transfer Binder] Fed. Sec. L. Rep. II 90,136, 90,317 (3d Cir. Feb. 12, 1998), vacated on grant of rehearing, 1998 U.S. App. LEXIS 4121 (Mar. 9, 1998), at 90,325 (holding that a defendant's participation in the creation of a fraudulent statement may 
the documents are fraudulent, the lawyer's conduct may be a sufficient basis upon which to impose liability as a primary violator for federal securities fraud. Under this approach, a secondary defendant could incur liability for his or her participation in the creation of fraudulent statements issued by someone else. ${ }^{11}$

The Second Circuit's approach has been different. In its most recent decision to address the issue, Wright $v$. Ermst E Young, ${ }^{12}$ the Second Circuit employed a narrower standard for liability, ${ }^{13}$ holding that "a secondary actor cannot incur primary liability under the [Securities Exchange] Act for a statement not attributed to that actor at the time of its dissemination." 14 The court rejected the argument that a defendant could be liable based upon his or her substantial participation in the creation of fraudulent documents, reasoning that any conduct by the defendant short of actually making a false and misleading statement was merely aiding and abetting, rather than a basis for primary liability. ${ }^{15}$

The disagreement between the Klein court and the Wright court stems from differing interpretations of Central Bank. More importantly, these decisions share an unduly restrictive interpretive approach-an effort to determine the scope of liability from the text of section 10 (b). The appropriate application of Central Bank has been complicated, however, by subsequent legislative developments: the enactment of two amendments to the federal securities laws that reform private civil litigation. The Private Securities Litigation Reform Act of $1995^{16}$ (the Reform Act) dealt with perceived abuses by revising a variety of procedural and substantive aspects of private litigation, including explicit modification of the liability standards for secondary defendants. ${ }^{17}$ More recently, the Securities Litigation Uniform Standards Act of $1998^{18}$ (the Uniform Standards Act) preempted state statutory and common law securities fraud

render him liable as a primary violator even if an investor is unable to attribute the statement to the defendant).

11. The Third Circuit subsequently vacated the panel decision and ordered reargument en banc. See Klein v. Boyd, 1998 U.S. App. LEXIS 4121 (Mar. 9, 1998). Before the case could be reargued, the parties settled, depriving the Third Circuit of the opportunity to resolve the scope of liability for secondary defendants. See Klein v. Boyd, Nos. 97-1143 and 97-1261 (Nov. 12, 1998) (order of the Third Circuit Clerk dismissing the case with prejudice in accordance with the agreement of the parties).

12. 152 F.3d 169 (2d Cir. 1998).

13. Cf. SEC v. First Jersey Securities, 101 F.3d 1450, 1471 (2d Cir. 1996) (holding that "primary liability may be imposed 'not only on persons who made fraudulent misrepresentations but also on those who had knowledge of the fraud and assisted in its preparation.'" (citation omitted)).

14. Wright, 152 F.3d at 175.

15. See id. (distinguishing between the "bright line" test and the "substantial participation" test).

16. Pub. L. No. 104-67, 109 Stat. 737 (1995) (codified at 15 U.S.C. $\S \S 77(a)$ et seq. (1994 \& Supp. I 1995)).

17. See infra notes 70-74 and accompanying text.

18. Pub. L. No. 105-353, 112 Stat. 3227 (1998). 
claims by requiring class actions involving nationally traded securities to be brought exclusively in federal court under uniform federal standards. ${ }^{19}$ Although lower courts struggling with the development of liability standards for secondary defendants have sought to reconcile their conclusions with Central Bank, they have given little attention to the potential impact of these statutes upon the basis for Central Bank's holding.

The reconciliation effort illustrates a key tension in the interpretation of section $10(\mathrm{~b})$ - the tension between the application of a Supreme Court precedent interpreting a federal statute and subsequent legislation that relates to the subject of the decision without directly addressing it. Because section 10(b) jurisprudence reflects an ongoing lawmaking dialogue between Congress and the federal courts, the current textualist methodology of statutory interpretation provides an inadequate tool for addressing this tension. The recent politically charged congressional incursions into the field of private securities litigation provide further reason to question the traditional orthodoxy of legislative deference. ${ }^{20}$

This Article begins by summarizing, in Part I, the Supreme Court's decision in Central Bank and explaining how the lower courts have attempted to apply Central Bank to determine the scope of primary liability for outside professionals under section 10(b). In Part II, the Article identifies two important legislative developments that postdate Central Bank: the adoption of the Reform Act and the Uniform Standards Act. The Article then analyzes, in Part III, the methodology of Central Bank, and argues that the textualist interpretation espoused by the Court in that case is inappropriate. Instead, the Article advocates a broader approach, in which courts consider, among other things, the effect of the recent statutes and the policy objectives identified by Congress in those statutes. In Part IV, the Article applies its suggested approach to the problem of delineating the appropriate scope of primary liability. The Article argues that the statutes expressly endorse the continued importance of liability for outside professionals while, at the same time, instituting reforms addressed at the litigation abuses perceived by the Central Bank Court. Accordingly, the Article concludes that recent decisions have been unduly restrictive in their reading of section 10 (b) liability and advocates more fidelity to the statutory purpose. The Article suggests that courts should give greater consideration to the nature of the professional's relationship

19. See, e.g., Richard W. Painter, Responding to a False Alarm: Federal Preemption of State Securities Fraud Causes of Action, 84 Cornell L. Rev. 1 (1998) (describing scope of Uniform Standards Act).

20. See, e.g., Douglas M. Branson, Chasing the Rogue Professional After the Private Securities Litigation Reform Act of 1995, 50 SMU L. Rev. 91, 93 n.6 (1996) (describing lobbying efforts for securities litigation reform and observing that the coalition lobbying for the legislation "amassed an early $\$ 12$ million war chest, mostly from the accounting profession"); Anthony Q. Fletcher, Note, Curing Crib Death: Emerging Growth Companies, Nuisance Suits, and Congressional Proposals for Securities Litigation Reform, 32 Harv. J. on Legis. 493 n.2 (1995) (describing coalition formed to lobby for litigation reform under the name Committee to Eliminate Abusive Securities Suits (CEASE)). 
with his or her client and the role of liability in enhancing the functioning of professionals as gatekeepers and furthering the integrity of the securities markets.

\section{The Problem of Liability of Outside Professionals: The Legacy OF CENTRAL BANK}

\section{A. The Central Bank Decision}

In Central Bank, the Supreme Court concluded that section $10(\mathrm{~b})^{21}$ does not permit liability to be imposed upon those who aid and abet federal securities fraud. ${ }^{22}$ The decision came with little warning-courts and commentators had widely accepted the validity of aiding and abetting liability. ${ }^{23}$ The petitioner in Central Bank did not even raise the issue until the Court issued a sua sponte order requiring the parties to address it. $^{24}$ Nonetheless, after rejecting the analysis of every lower court to consider the question, ${ }^{25}$ the Court concluded that, because section 10 (b) did not contain the terms "aiding and abetting," the scope of the statute did not extend beyond primary liability. ${ }^{26}$

\section{Section $10(\mathrm{~b})$ provides:}

It shall be unlawf ul for any person, directly or indirectly, by the use of any means or instrumentality of interstate commerce or of the mails, or of any facility of any national securities exchange-

(b) To use or employ, in connection with the purchase or sale of any security registered on a national securities exchange or any security not so registered, any manipulative or deceptive device or contrivance in contravention of such rules and regulations as the Commission may prescribe as necessary or appropriate in the public interest or for the protection of investors.

Securities and Exchange Act of 1934, 15 U.S.C. § 78j(b) (1994).

22. See Central Bank v. First Interstate, 511 U.S. 164, 177 (1994).

23. See, e.g., Richard J. Pierce, Jr., The Supreme Court's New Hypertextualism: An Invitation to Cacophony and Incoherence in the Administrative State, 95 Colum. L. Rev. 749, 760 (1995) (explaining that until Central Bank, "no court had suggested any doubt" that section 10(b) should be interpreted to impose liability for aiding and abetting securities fraud).

24. See id. See also Central Bank, 511 U.S. at 194-95 (1994) (Stevens, J., dissenting) (criticizing the Court for reaching out to overturn a body of settled law).

25. See Brief of the Association of the Bar of the City of New York, Amicus Curiae, in Central Bank v. First Interstate, 511 U.S. 164 (1994), available in Lexis, 1992 U.S. Briefs 854 [hereinafter City Bar Amicus Brief in Central Bank]. The extensive lower court decisions had refined a test for secondary liability that required: 1) the existence of a primary violation; 2) scienter by the defendant; and 3) substantial assistance of the violation by the defendant. See The Supreme Court, 1993 Term-Leading Cases, 108 Harv. L. Rev. 139, 362 n.3 (1994) (describing scope of aiding and abetting liability at the time of the Central Bank decision); see also Jill E. Fisch, Retroactivity and Legal Change: An Equilibrium Analysis, 110 Harv. L. Rev. 1055, 1104-05 (1997) (describing legal status of aiding and abetting liability as in a stable equilibrium prior to Central Bank).

26. 511 U.S. at 191 ("Because the text of $\S 10$ (b) does not prohibit aiding and abetting, we hold that a private plaintiff may not maintain an aiding and abetting suit under $\S 10(\mathrm{~b}) . ")$. 
In reaching this result, the Central Bank Court employed a strict textualist approach. ${ }^{27}$ The Court defended its reliance on the statutory text, in part, by using a distinction that it had recognized in only one other case, ${ }^{28}$ between statutory interpretation issues involving the scope of conduct prohibited by section 10 (b) and questions about the elements of the liability scheme. ${ }^{29}$ The Central Bank opinion explained that aiding and abetting liability involved a scope of conduct issue and that, accordingly, the text of the statute was controlling. ${ }^{30}$ Nonetheless, the Court explicitly stated that outside professionals could still be liable under section 10 (b) as long as the requirements for primary liability were met. ${ }^{31}$

The Central Bank decision proceeded to buttress its conclusion with arguments about congressional intent and policy considerations. ${ }^{32}$ Faced with congressional silence, the Court refused to infer a broad intention to supplement primary liability with aiding and abetting liability, either in section 10 (b) or generally throughout the Exchange Act. ${ }^{33}$ The Court observed that Congress had made a deliberate choice about the scope of secondary liability by explicitly creating liability for controlling persons in section 20. ${ }^{34}$ In addition, the majority opinion noted that Congress had enacted the Exchange Act against a regulatory backdrop in which many state blue sky laws imposed aiding and abetting liability. ${ }^{35}$ Finally, the opinion rejected arguments that subsequent Congresses had acquiesced in or ratified aiding and abetting liability. ${ }^{36}$ The Court was unconvinced that legislative references to aiding and abetting constituted ratification, noting that these references were not the product of the formal legislative process. ${ }^{37}$ The decision also concluded that Congress's failure to overturn judicial decisions upholding aiding and abetting liability was not the equivalent of congressional approval. ${ }^{38}$

The majority opinion similarly rejected policy arguments that aiding and abetting liability deters secondary actors from furthering fraudulent schemes and increases victim compensation. ${ }^{39}$ The Court warned that it was precluded from using policy considerations as a basis for overriding

27. See Richard H. Walker \& David M. Levine, The Limits of Central Bank's Textualist Approach-Attempts to Overdraw the Bank Prove Unsuccessful, 26 Hofstra L. Rev. 1, 3 (1997).

28. Musick, Peeler \& Garrett v. Employers Ins. of Wausau, 508 U.S. 286 (1993).

29. See Central Bank, 511 U.S. at 172-73.

30. See id. at 177 .

31. See id. at 191 .

32. 2. See id. at 178-90.

33. See id. at $180-85$.

34. See id. at 184. Section 20 imposes liability on "controlling persons," that is, those who "control any person liable under any provision of this chapter or of any rule or regulation thereunder." 15 U.S.C. $§ 78 \mathrm{t}(\mathrm{a})$.

35. See Central Bank, 511 U.S. at 184.

36. See id. at 186 .

37. See id. at $186-87$.

38. See id. at 188-90.

39. See id. at 185-87. 
the statutory text. ${ }^{40}$ Nonetheless, the Court went out of its way to describe why recognition of aiding and abetting liability was inconsistent with the statutory objectives inasmuch as it would "exact[ ] costs that may disserve the goals of fair dealing and efficiency in the securities markets." 41 The majority opinion explained that secondary liability is often imposed in an unpredictable manner and that, as a result, secondary defendants may suffer undue settlement pressure. ${ }^{42}$ The opinion also identified federal securities fraud as presenting a danger of vexatious litigation. ${ }^{43}$ The Court viewed this litigation risk as particularly problematic for outside professionals because it could cause them to withhold their services from new and smaller companies or to pass the costs of litigation on to investors. ${ }^{44}$

Thus, the task for lower courts after Central Bank has been to define the circumstances under which secondary defendants meet the requirements for primary liability. Central Bank offers limited guidance in this endeavor. The Court's opinion did not address the scope of liability for secondary defendants. Moreover, although determining when the conduct of outside professionals violates section 10(b) appears to involve a scope of conduct question analogous to that in Central Bank, strict textualism is of limited value in ascertaining the scope of liability for secondary defendants. ${ }^{45}$ Section 10 (b) is, of course, silent even with respect to the imposition of primary liability. If a court nonetheless concludes, as the federal courts have done consistently, that the statutory text imposes liability upon anyone who uses or employs a manipulative or deceptive device, there are no statutory guidelines as to acceptable defendants. In cases in which secondary defendants are acting together with and on behalf of a client-issuer, and the relevant disclosures are made by and on behalf of the client, the text offers no tools for drawing a line between those who have committed the fraud and those who should be treated as collateral participants.

40. See id. at 188 ("Policy considerations cannot override our interpretation of the text and structure of the Act, except to the extent that they may help to show that adherence to the text and structure would lead to a result 'so bizarre' that Congress could not have intended it.").

41. See id. at 184 .

42. See id.

43. See id. at 189 .

44. See id.

45. Indeed, the Central Bank decision itself seems to recognize that the analysis employed would not be useful in ascertaining the elements of an acknowledged cause of action. See Robert A. Prentice, Locating that "Indistinct" and "Virtually Nonexistent" Line Between Primary and Secondary Liability Under Section 10(b), 75 N.C. L. Rev. 691, 712 (1997) (arguing that neither Central Bank's method of analysis nor its holding is relevant to determining the proper parameters of primary liability). 


\section{B. The Application of Central Bank}

Recent decisions have sought to apply Central Bank's reasoning in an effort to develop liability standards for secondary defendants. Cases at both ends of the liability spectrum are relatively easy to resolve. Central Bank expressly endorses the concept of primary liability for outside professionals who make fraudulent statements. ${ }^{46}$ Thus, when a lawyer or accountant is sued on the basis of his or her own statements rather than those of the client, the professional faces primary liability under the statute. ${ }^{47}$ Such liability may arise, for example, from misrepresentations contained in an opinion letter. ${ }^{48}$ Conversely, Central Bank seems to eliminate liability based upon pure gatekeeper or whistleblower theories of liability, in which an outside professional is sued for his or her inaction in failing to prevent a client's fraud. ${ }^{49}$ At least in circumstances in which the professional owes no duty to the victims of the fraud, the failure to act or to speak is insufficient for the imposition of primary liability. ${ }^{50}$

The cases in between are more troubling. Traditionally, issuers have engaged outside professionals to assist in the task of preparing the issuer's disclosure documents. This assistance can take the form of advising the client on disclosure requirements, drafting the necessary documentation, and verifying that the client's disclosure is accurate and complete. ${ }^{51}$ In evaluating the potential liability of outside professionals based upon this role, one possible approach is to adopt a bright line rule that the client alone is responsible for the contents of its disclosure documents. ${ }^{52}$ A few courts, such as those in the Second Circuit, have followed this approach, reasoning that for Central Bank to have any meaning a de-

46. See supra note 6 .

47. See, e.g., McGann v. Ernst \& Young, 102 F.3d 390, 397 (9th Cir. 1996) (concluding that accounting firm could be liable for its fraudulent audit report, which was included in client's Form 10-K and filed with the SEC). Although pre-Central Bank cases often termed this secondary liability, Central Bank makes it clear that this characterization was incorrect. See Prentice, supra note 45, at 707 (explaining that liability for one's own misrepresentations is primary, not secondary).

48. See, e.g., Kline v. First Western Gov't Sec., 24 F.3d 480, 486-87 (3d Cir. (1994).

49. See Prentice, supra note 45, at 765-66 (explaining why the Central Bank decision should eliminate whistleblower liability).

50. The decision in SEC v. National Student Marketing Corp., 457 F. Supp. 682 (D.D.C. 1978), is one of the better known examples of a situation in which attorneys were held responsible for their failure to take action to stop a transaction once they learned of the use of false financial data. The court did not rely upon the existence of any duty to the victims as a basis for imposing liability. See id. at 713 .

51. See, e.g., Manning Gilbert Warren III, The Primary Liability of Securities Lawyers, 50 SMU L. Rev. 383, 387-90 (1996) (describing the role of the securities lawyer in assisting a client with the disclosure process).

52. See, e.g., Anixter v. Home-Stake Production Co., 77 F.3d 1215, 1226-27 (10th Cir. 1996) (adopting this approach, although describing it as "far from a bright line [rule]"); see also Patricia Blanchini, Note, The Statement Someone Else Makes May be Your Own: Primary Liability Under Section 10(b) After Central Bank, 71 St. John's L. Rev. 767, 786-87 (1997) (criticizing this approach as inconsistent with Central Bank and the intent of Congress). 
fendant must actually make a false and misleading statement rather than aid someone else. ${ }^{53}$ This approach is supported both by the text of the statute and by the concern articulated in Central Bank that the application of liability standards be sufficiently predictable. ${ }^{54}$

Other courts, particularly those in the Ninth Circuit, have rejected the bright line rule in favor of the conclusion that liability can be imposed upon outside professionals who substantially participate in the disclosure process, even if the documents prepared do not purport to be statements by the professional. ${ }^{55}$ The Third Circuit panel in Klein v. Boyd justified this result by explaining that sufficient assistance makes the professional a co-author of the documents, thereby rendering the professional accountable for misrepresentations or omissions in those documents. ${ }^{56}$ Similarly, courts have reasoned that primary liability may extend to all members of the "drafting group." 57 The SEC has advocated primary liability for an outside professional who "acting alone or with others, creates a misrepresentation."58 Under this theory, the secondary

53. See Shapiro v. Cantor, 123 F.3d 717, 720 (2d Cir. 1997). Even under the Second Circuit approach, a primary violator need not communicate directly with investors. Rather, liability is appropriate whenever a defendant is the source of a fraudulent misrepresentation and knows or should know that the misrepresentation will be communicated to investors. See, e.g., In re Kidder Peabody Securities Litig., 10 F. Supp. 2d 398, 407 (S.D.N.Y. 1998). Related to this is the conclusion that an outside professional may be primarily liable for fraud committed through his or her direct contacts with investors. See, e.g., Rubin v. Schottenstein, Zox \& Dunn, 143 F.3d 263, 267 (6th Cir. 1998) (holding that attorney and his law firm could be primarily liable based on "direct contacts" with the plaintiffs). See also Mishkin v. Ageloff, 1998 WL 651065 (S.D.N.Y. Sept. 23, 1998), slip op. at 18 (finding allegations that defendant participated in a fraudulent scheme or committed a fraudulent act sufficient to state a claim for primary liability where defendant was a principal actor rather than an outside professional).

54. See Shapiro, 123 F.3d at 720 (defending this approach as providing more guidance to outside professionals than a rule allowing liability to attach to those who provide substantial or significant assistance to the representations of others); accord Anixter, 77 F.3d at 1226.

55. See, e.g., In re Software Toolworks, Inc. Sec. Litig., 38 F.3d 1078, 1090 n.3 (9th Cir. 1994) (finding accounting firm's significant participation in drafting misleading letters to the SEC sufficient to support a claim of primary liability); Cashman v. Coopers \& Lybrand, 877 F. Supp. 425, 433 (N.D. Ill. 1995) (holding that primary liability could be based upon accountant's central role in the drafting and formation of misrepresentations); In re ZZZZ Best Sec. Litig., 864 F. Supp. 960, 970 (C.D. Cal. 1994) (holding that liability can be based upon an accounting firm's intricate involvement in creating false documents).

56. Fed. Sec. L. Rep. (CCH) If 90,136, 90,325.

57. See In re Software Toolworks, Inc. Sec. Litig., 50 F.3d 615, 629 (9th Cir. 1994); see also Murphy v. Hollywood Entertainment Corp., Fed. Sec. L. Rev. (CCH) I 99,241, 99,347 (D. Or. 1996) (upholding as sufficient allegations that underwriters were "'direct participants'" in the alleged wrongdoing by their role in coordinating the offering, drafting disputed offering documents and conducting a due diligence investigation").

58. Brief of the Securities and Exchange Commission, Amicus Curiae 14, in Klein v. Boyd, Nos. 97-1143, 97-1261 (3d Cir. 1997) (visited Apr. 1, 1999) <http:// www.sec.govnews/legal/klein.txt> [hereinafter SEC Amicus Brief in Klein] (on file with the Columbia Law Review). 
defendant need not sign or certify the disclosure documents. ${ }^{59}$ Indeed, the secondary defendant's role or identity need not even be known to potential investors; his or her participation is sufficient. ${ }^{60}$

Although courts have claimed that this approach is consistent with Central Bank because it only imposes liability upon those who make misrepresentations (as opposed to those who provide substantial assistance), premising liability upon a prof essional's participation in a collective process appears perilously close to the liability standard rejected by Central Bank. ${ }^{61}$ Moreover, even if one accepts the premise that an outside professional's participation in the preparation of fraudulent client disclosure should result in liability under appropriate circumstances, the difficulties in applying this approach raise additional concerns. Using this approach, courts have premised liability upon the degree of the professional's participation, explaining that the professional's involvement must be "substantial" or "significant." It is virtually impossible, however, to translate these terms into an articulable legal standard by which to quantify the level of participation necessary for the imposition of liability. This creates several problems.

First, imposing liability upon outside professionals based upon their level of participation is unpredictable and subject to an ad hoc fact-based evaluation. ${ }^{62}$ The Central Bank Court expressly identified an unpredictable standard of liability for outside professionals as undesirable. ${ }^{63}$ Second, the imposition of liability based upon a professional's degree of involvement may have the practical effect of punishing him or her for professionally responsible behavior. ${ }^{64}$ The purpose of engaging securities professionals is to obtain their assistance in the preparation of the required disclosure documents, yet, a professional who diligently assists the client in preparing these documents is thereby subjected to liability

59. See, e.g., Carley Capital Group. v. Deloitte \& Touche, L.L.P., Fed. Sec. L. Rep. (CCH) I 90,341, 91,635 (D. Ga. 1998) (accepting the standard of liability advocated by the SEC and concluding that this standard is "consistent with the 'directly or indirectly' language in Section 10(b)").

60. See SEC Amicus Brief in Klein, supra note 58, at 8-13 (arguing that a rule imposing liability only upon defendants who are identified to investors is inconsistent with Central Bank).

61. See Shapiro v. Cantor, 123 F.3d 717, 720 (2d Cir. 1997) (“Allegations of 'assisting,' 'participating in,' 'complicity in' and similar synonyms ... all fall within the prohibitive bar of Central Bank.").

62. The scienter requirement provides insufficient protection against liability due, in part, to its fact-based nature. In addition to the evidentiary problems posed by a professional's scienter defense, its imposition requires the defendant to go to trial, thereby incurring substantial litigation costs. These costs are the source of the settlement pressure identified by the Court in Central Bank.

63. See Central Bank v. First Interstate, 511 U.S. 164, 188 (1994).

64. See, e.g., Brief Amicus Curiae of the Association of the Bar of the City of New York 13, in Klein v. Boyd, Nos. 97-1143, 97-1261 (3d Cir. 1997) (on file with the Columbia Law Review) (warning that "it may not be possible for attorneys to satisfy professional standards of competence without being substantially involved in the drafting process") [hereinafter City Bar Amicus Brief in Klein]. 
precisely because he or she has provided meaningful assistance. Third, the standard encourages securities professionals to distance themselves from their client's product by refusing to draft, review, or verify client statements. This result sacrifices both the client's interests and those of outside investors who benefit from the involvement of outside professionals in the preparation process. ${ }^{65}$

The existing lower court decisions are currently in conflict both as to the legal standard they articulate and the application of that standard. However, if the courts were to adopt a rule that imposes liability based upon some level of participation in the preparation of client disclosure, the result may be substantially to limit the practical effect of Central Bank and to apply, in essence, the pre-Central Bank liability standards under the new name of primary liability. ${ }^{66}$ Apart from the question of whether this approach conflicts with Central Bank's reading of the statutory text, it raises concern over the policy considerations identified by the Court in Central Bank. These policy issues-the lack of predictability, the settlement pressure imposed by fact-based liability standards, and the risk of vexatious litigation-would persist under a substantial participation liability standard. ${ }^{67}$

\section{Recent Federal Securities Legislation}

In attempting to formulate a test for when outside professionals should be held liable for federal securities fraud, it is necessary to expand the analysis beyond Central Bank. Subsequent to Central Bank, Congress adopted two significant amendments to the federal securities laws that specifically address private civil litigation. With respect to all three factors identified by the Central Bank decision-statutory text, legislative intent, and policy considerations-the amendments offer additional insight about the appropriate scope of liability for secondary defendants.

The statutes directly addressed the perceptions of abusive and vexatious litigation that animated the Central Bank decision. In 1995, Con-

65. See, e.g., Warren, supra note 51, at 396 (arguing that investors rely upon the lawyer's work in making investment decisions).

66. See Donald C. Langevoort, Words from on High About Rule 10b-5: Chiarella's History, Central Bank's Future, 20 Del. J. Corp. L. 865, 869 (1995) (predicting that Central Bank decision would be a good candidate for lower court revisionism which could have the effect of substantially reducing the extent to which the decision changes the status quo).

67. Although few courts have experimented with other approaches, there are alternatives to both the bright line approach articulated in Wright and imposing liability based upon a sufficient degree of participation. It is possible, for example, to analogize to the Supreme Court's analysis in Pinter v. Dahl, 486 U.S. 622 (1988). In Pinter, the Court rejected the idea that primary liability as a seller under section 12 of the Securities Act of 1933 was limited to the owner of a security. Instead, the Court extended primary liability to include those who solicit the purchase of securities if they are motivated, at least in part, by a desire to serve their own financial interests or those of the issuer. See id. at 642-47. A court could similarly predicate primary liability under section 10 (b) on the defendant's financial interest, as well as participation, in the fraudulent transaction. 
gress overrode President Clinton's veto and adopted the Private Securities Litigation Reform Act. ${ }^{\text {i8 }}$ The Reform Act contained a variety of procedural and substantive reforms designed to reduce the volume of private securities fraud litigation and to curb litigation abuse. These reforms included a heightened pleading standard, a safe harbor for forward-looking statements, and the creation of a lead plaintiff to monitor litigation decisionmaking. ${ }^{69}$

The Reform Act directly addressed liability of secondary defendants in several ways. First, section 201 of the Reform Act ${ }^{70}$ replaced joint and several liability with a "fair share" system of proportionate liability for defendants who do not have actual knowledge of a fraud. ${ }^{71}$ Second, the Reform Act restored to the SEC the authority to proceed against those who aid and abet securities fraud. ${ }^{72}$ Significantly, however, Congress rejected efforts to provide a private right of action against aiders and abettors. ${ }^{73}$ Third, through the adoption of section 10A, the Reform Act broadened the duties of independent auditors by explicitly setting forth statutory requirements for an audit of issuer financial statements and by requiring that auditors who detect material illegal acts take specified remedial action. ${ }^{74}$

68. Reform Act, supra note 16.

69. See Jill E. Fisch, Class Action Reform: Lessons from Securities Litigation, 39 Ariz. L. Rev. 533, 534-37 (1997) (describing history of the Reform Act and concerns to which it was addressed); Joel Seligman, The Private Securities Reform Act of 1995, 38 Ariz. L. Rev. 717 (1996) (describing provisions of the Reform Act).

70. Pub. L. No. 104-67, 109 Stat. 737, 758-59 (1995) (amending section 21D of the Securities Exchange Act of 1934).

71. The Conference Report describes this provision as addressing "[o]ne of the most manifestly unfair aspects of the current system of securities litigation." H.R. Conf. Rep. No. 369, 104th Cong., 1st Sess. 37 (1995), reprinted in 1995 U.S.C.C.A.N. 730, 736. See also Melissa Harrison, The Assault on the Liability of Outside Professionals: Are Lawyers and Accountants Off the Hook?, 65 U. Cin. L. Rev. 473, 518-21 (1997) (describing proportionate liability provision). The proportionate liability provision contains two exceptions: 1) secondary defendants are jointly and severally liable to plaintiffs who prove damages exceeding ten percent of their net worth and whose net worth is less than $\$ 200,000$; and 2) secondary defendants are liable for an additional payment of up to fifty percent if another defendant is insolvent and unable to pay its respective share of damages. See id. at 518-19.

72. See 15 U.S.C.A. § 78t(f) (West 1997).

73. For example, Senator Bryan introduced Amendment 1474, which was designed to overrule Central Bank and to provide for a private right of action against aiders and abettors. See 141 Cong. Rec. S9109-9116 (daily ed. June 27, 1995). The Amendment was rejected by Congress. See Broady R. Hodder, Note, Central Bank v. First Interstate Bank and Its Aftermath: Securities Professionals' Ever-Changing Liabilities, 39 Ariz. L. Rev. 343, 357-58 (1997) (describing defeated efforts in Congress to restore aiding and abetting liability).

74. 15 U.S.C. $\S 78 j-1(a)-(b)$ (Supp. I 1995). The SEC subsequently adopted rules to implement $\S 10 \mathrm{~A}$. See Implementation of Section 10A of the Securities Exchange Act of 1934, SEC Release No. 34-38387, 62 Fed. Reg. 12,743 (1997). See also Marc I. Steinberg, Securities Law After the Private Securities Litigation Reform Act-Unfinished Business, 50 
Subsequent to the adoption of the Reform Act, Congress heard complaints that some of the Reform Act's effectiveness was being undercut by state court litigation. ${ }^{75}$ Although the extent of the problem was seriously disputed, ${ }^{76}$ Congress responded by passing the Securities Litigation Uniform Standards Act of 1998, which President Clinton signed in October of 1998. ${ }^{77}$ The Uniform Standards Act adopted a uniform federal standard for class action litigation involving fraud in connection with transactions in nationally traded securities. ${ }^{78}$ The effect of the statute was to preempt state law causes of action for fraud, retaining, with certain exceptions, federal liability as the exclusive remedy for investors. ${ }^{79}$ Thus, the Uniform Standards Act eliminated the ability of plaintiffs to avoid the limitations of the Central Bank decision by proceeding against secondary defendants under state law. ${ }^{80}$

\section{Questions of Statutory Interpretation-The Continued SignifiCanCe OF CENTRAL BANK}

Courts and commentators have devoted little analysis to whether the adoption of the Reform Act and the Uniform Standards Act should influence the continued significance of Central Bank. In part, this question depends upon understanding the rationale for the Central Bank decision. The Central Bank opinion claims to place primary reliance on a narrow interpretation of the text of section $10(\mathrm{~b})$. This textualism is consistent with current Supreme Court jurisprudence. ${ }^{81}$ Regardless of the general appropriateness of textualism as a method of statutory interpretation, ${ }^{82}$ it

SMU L. Rev. 9, 12-13 (1996) (describing new audit, notification and reporting requirements imposed on auditors).

75. See, e.g., Richard H. Walker, Evaluating the Preemption Evidence: Have the Proponents Met Their Burden?, 60 Law \& Contemp. Prob. 237 (1997) (describing and evaluating arguments that effectiveness of certain Reform Act provisions was reduced by migration of litigation to state court).

76. See id. at $248-49$.

77. Pub. L. No. 105-353, 112 Stat. 3227 (codified in scattered sections of 15 U.S.C.).

78. See Statement by the President, U.S. Newswire, Nov. 3, 1998, available in 1998 WL 13607107 (describing effect of legislation as providing "uniform national standards" for class actions).

79. See generally Painter, supra note 19 (describing effect of the Uniform Standards Act).

80. See, e.g., Branson, supra note 20, at 116-20 (describing ways in which state law offers broader recourse against collateral defendants than federal securities law after the Reform Act and Central Bank).

81. See, e.g., Pierce, supra note 23, at 750 (1995) (describing Court's increasing reliance on textualism during period from 1982 to 1992 and reduced use of legislative purpose and history); see also William N. Eskridge, Jr., The New Textualism, 37 UCLA L. Rev. 621, 624 (1990) (describing Justice Scalia's "new textualism" as "the most interesting development in the Court's legisprudence (the jurisprudence of legislation) in the 1980s").

82. Cf. Melvin A. Eisenberg, Strict Textualism, 29 Loy. L.A. L. Rev. 13 (1995) (arguing that strict textualism is both intellectually incoherent and illegitimate because it renders the judiciary unfaithful to the legislature). 
is not clear that its heavy emphasis on the statutory text is an appropriate methodology for interpreting the federal securities laws. ${ }^{83}$

\section{A. The Role of Textualism in Interpreting Federal Securities Law}

There are several reasons to be wary of textualism in the securities area. ${ }^{84}$ First, the federal securities laws contain a number of provisions in which the statutory text is limited and the legislative history sparse. ${ }^{85}$ This structure is partially due to the age of the legislation-modern statutes frequently contain highly detailed enumeration of permitted claims, authorized claimants, available remedies, and so forth. The evolution toward greater statutory detail has been influenced by Supreme Court decisions that impose affirmative drafting obligations upon Congress. ${ }^{86}$ Yet, the federal securities laws were passed in an era that predates those obligations. ${ }^{87}$ As a consequence, decisions such as J.I. Case v. Borak, ${ }^{88}$ which recognize a private right of action under a statute that does not explicitly provide one, reflect a common law approach to statutory interpretation that is currently disfavored. ${ }^{89}$

83. The Supreme Court has vacillated in its use of textualism to interpret the federal securities laws. Compare Landreth Timber Co. v. Landreth, 471 U.S. 681, 685 (1985) (textualist approach requires Court to reject sale of a business doctrine in determining whether stock is within the statutory definition of a security) with Reves v. Emst \& Young, 494 U.S. 56, 62 (1990) (declining to rely exclusively on statutory text to determine when a note is a security).

84. In addition to the criticisms detailed here, commentators have argued that textualism is ill-suited for securities jurisprudence because of the difficulty in identifying the relevant statutory text. See, e.g., Eisenberg, supra note 82, at 22.

85. See, e.g., Joseph A. Grundfest, We Must Never Forget that It Is an Inkblot We Are Expounding: Section 10(b) as a Rorschach Test, 29 Loy. L.A. L. Rev. 41, 43 (1995) (describing the federal securities laws, and section 10(b) in particular, as an "inkblot").

86. See, e.g., Landgraf v. USI Film Products, 511 U.S. 244, 280 (1994) (refusing to apply statute retroactively unless Congress so instructs); Tafflin v. Levitt, 493 U.S. 455 (1990) (requiring express direction by Congress to override presumption of concurrent state and federal jurisdiction over federal claims); Atascadero State Hospital v. Scanlon, 473 U.S. 234, 238 (1985) (requiring "unequivocal expression of congressional intent" to exercise its power under the Fourteenth Amendment to abrogate state sovereign immunity).

87. See Cannon v. University of Chicago, 441 U.S. 677, 698-99 (1979) (recognizing that analysis of whether Congress intended to create a private right of action must consider contemporary legal context, and that for statutes passed during an era in which courts consistently found implied remedies, it is appropriate to presume that Congress expected the statutes to be interpreted in conformity with that approach); see also Merrill Lynch, Pierce, Fenner \& Smith, Inc. v. Curran, 456 U.S. 353, 381 (1982) (implying a private right of action under the Commodity Exchange Act on the theory that such a remedy was intended by the Congress that enacted the statute as a result of the contemporary legal context); Eisenberg, supra note 82, at 38 (arguing that strict textualism should not be applied to statutes that were drafted when it was not the official methodology for statutory interpretation).

88. 377 U.S. 426 (1964) (recognizing an implied private right of action under section 14(a) of the Securities Exchange Act of 1934, 15 U.S.C. $\S 578$ n(a) (1998)).

89. Indeed, at least one commentator has noted the irony in the Central Bank decision's reliance on textualism to reject aiding and abetting liability and, "in the same 
Second, the statutory structure of federal securities regulation, particularly the Securities Exchange Act of 1934, has led Congress to give little attention to weighing the policy issues inherent in securities regulation and itself tailoring an enforcement mechanism to address particularized policy objectives. In part, this has resulted from Congress delegating substantial rulemaking and enforcement power ${ }^{90}$ to the Securities and Exchange Commission. ${ }^{91}$ In retrospect, this delegation seems appropriate- the SEC may be better able to respond in a rapid and nuanced manner to the technical and frequently changing securities industry with the tools of an administrative agency than could Congress through refinements to the statutory text. ${ }^{92}$ In exercising its delegated authority, the SEC has relied heavily upon a joint public and private system of enforcement, in which private civil litigation supplements government enforcement efforts. ${ }^{93}$ The SEC's effort to strike a balance and to maintain appropriate levels of enforcement accordingly bears a limited connection to the statutory text.

Third, the unstructured nature of the federal securities laws has also led to greater judicial activism. Congress deliberately drafted the securities laws broadly to enable the regulatory scheme to address new developments in the industry including the development of new methods of fraud. ${ }^{94}$ The federal courts responded to this challenge by interpreting the statutes in a manner that furthers Congress's remedial objectives. The implication of a private right of action under provisions such as sections 14(a) and 10(b) is an example of this approach; the Court's motivation in Borak was to allow private litigation to supplement public enforcement. ${ }^{95}$ As a result, whole areas of securities regulation have little or no origin in the text of the statute, but rather are the creations of federal

breath," recognizing an implied private right of action against primary violators. Ediberto Roman, Statutory Interpretation in Securities Jurisprudence: A Failure of Textualism, 75 Neb. L. Rev. 377, 407 (1996).

90. See, e.g., Natural Resources Defense Council Inc. v. SEC, 606 F.2d 1031, 1050 (D.C. Cir. 1979) (describing broad congressional grant of rulemaking authority to the SEC and citing various statutory examples); SEC v. Materia, 745 F.2d 197, 200 (2d Cir. 1984) (explaining broad enforcement power of SEC).

91. Congress created the Securities and Exchange Commission in section 4 of the Exchange Act, 15 U.S.C. $\S 78 d$.

92. See Amy E. Fahey, Note, United States v. O'Hagan: The Supreme Court Abandons Textualism to Adopt the Misappropriation Theory, 25 Fordham Urb. L.J. 507, 533 (1998).

93. See Aiding and Abetting Liability Under the Federal Securities Laws: Hearings on the Impact of the Supreme Court's Decision in Central Bank Before the Subcommittee on Securities of the Senate Committee on Banking, Housing, and Urban Affairs, 103d Cong., 2d Sess. (1994), available in 1994 WL 233142, at *10-11 (statement of Arthur Levitt, Chairman, SEC) (testifying that SEC cannot pursue every violation of federal securities laws and that private actions serve as a necessary complement to SEC enforcement actions).

94. See Walker \& Levine, supra note 27, at 4-5 (arguing that, because Congress intentionally drafted the federal securities broadly, strict textualism is poorly suited to interpreting them).

95. See Tamar Frankel, Implied Rights of Action, 67 Va. L. Rev. 553, 557 (1981). 
common law. ${ }^{96}$ Private civil liability under section 10 (b) and insider trading liability are two prominent examples. ${ }^{97}$ Given the extent to which judicial lawmaking has occupied the field of securities regulation, congressional fine-tuning is virtually impossible unless Congress accepts the legal framework created by the courts. ${ }^{98}$ In fact, Congress appears to have done so; in adopting subsequent amendments to the federal securities laws, Congress has repeatedly expressed its approval of the courts' decisions in these areas. ${ }^{99}$

These concerns, and others, support the Supreme Court's earlier approach to interpreting the federal securities laws-an approach consistent with the recognition of an implied private right of action for federal securities fraud. The Court's original approach-whether described as purposivist, intentionalist or structuralist-was characterized by the Court's willingness to inform its interpretation by policy arguments as well as text and legislative history. ${ }^{100}$

Central Bank has been widely cited as demonstrating the current Court's commitment to strict textualism and rejection of interpretive principles that incorporate policy arguments. Recent Supreme Court decisions, however, suggest that the Central Bank decision may be more of an aberration than it initially appeared. In Gustafson v. Alloyd Co., for example, which was decided only a year after Central Bank, the majority opinion purported to use a textualist analysis, yet rejected the explicit statutory definition of a prospectus as inconsistent with legislative intent. ${ }^{101}$ As the dissenters in Gustafson pointed out, although it claims to apply textualism, the majority's opinion can only be explained on policy grounds. ${ }^{102}$ Indeed, commentators have criticized the Court's tortured effort to manipulate the statutory text as a threat to the very coherence of

96. See Steven Thel, Section 12(2) of the Securities Act: Does Old Legislation Matter?, 63 Fordham L. Rev. 1183, 1198 (1995) (arguing that recent securities legislation "can fairly be read" as congressional delegation of broad law-making authority to courts).

97. See Steve Thel, Statutory Findings and Insider Trading Regulation, 50 Vand. L. Rev. 1091, 1134 (1997) ("The judge-made law of rule 10b-5 has already largely supplanted enacted statutes as the primary vehicle of securities regulation.").

98. See id.

99. See Thel, supra note 96, at 1200 ("In the Sanctions Act, the Enforcement Act and the limitations legislation, Congress has acknowledged that the courts make the law of private liability for securities fraud and established a regime that contemplates the courts' continuing to do so.").

100. See William N. Eskridge, Jr., Dynamic Statutory Interpretation 323-33 (1994) (describing different methodologies of statutory interpretation employed by the Court).

101. 513 U.S. 561, 581-82 (1995) (reasoning from legislative history that Congress did not intend to extend liability under section $12(2)$ to every private or secondary sale of securities, despite statutory language suggesting such a result).

102. See id. at 594 (Thomas, J., dissenting) ("The majority's analysis of $\S 12(2)$ is motivated by its policy preferences."); id. at 596 (Ginsburg, J., dissenting) (criticizing majority for statutory construction supported by "impressive policy reasons" but inconsistent with "statute's defining text"); see also id. at 590-01 (Thomas, J., dissenting) (criticizing majority opinion's methodology as inconsistent with the approach taken in Central Bank). 
the statutory structure. ${ }^{103}$ Nonetheless, even critics of the Court's methodology concede that, from a policy perspective, the decision reached the correct result. ${ }^{104}$ Accordingly, despite the obvious differences between section 12(2), the statutory provision at issue in Gustafson, and section 10 (b), the decision may signal the Court's willingness to abandon a textualist result that is inconsistent with the logic of the regulatory structure or industry practice. ${ }^{105}$

Subsequently, the Court more candidly rejected strict textualism in analyzing the application of section $10(\mathrm{~b})$ to insider trading. In United States v. O'Hagan, ${ }^{106}$ the Supreme Court refused to use either the methodology of Central Bank or the language of section 10 (b) as a basis for rejecting the misappropriation theory. ${ }^{107}$ Despite the seeming suitability of Central Bank to the question of whether misappropriation is within the scope of conduct regulated by section $10(\mathrm{~b})$, the Court did not use the scope of conduct test in its analysis. In addition, and more importantly, the O'Hagan Court distinguished the Central Bank decision on the grounds that it was addressed to private litigation ${ }^{108}$ and motivated by policy considerations. ${ }^{109}$ Thus, O'Hagan suggests that the Court may be reconsidering the validity of strict textualism within the context of securities jurisprudence. ${ }^{110}$

103. See, e.g., The Supreme Court, 1994 Term—Leading Cases, 109 Harv. L. Rev. 111, 336-39 (1995).

104. See Stephen M. Bainbridge, Securities Act Section 12(2) After the Gustafson Debacle, 50 Bus. Law. 1231, 1270 (1995); The Supreme Court, 1994 Term-Leading Cases, supra note 103, at 338-39 (acknowledging that "majority's ultimate holding . . is widely perceived to be beneficial for policy reasons").

105. See, e.g., Therese Maynard, A Requiem: Reflections on Gustafson, 57 Ohio St. L.J. 1327 (1996) (describing and criticizing the Gustafson Court's disregard for the statutory language and structure); Brian E. Burns, Comment, Red Means Green: The Disruption of the Statutory Construction Process in Gustafson to Harmonize Section 12(2) and Rule 10b-5 Private Liability Actions Under the Federal Securities Laws, 57 Ohio St. L.J. 1365, 1389 (1996) (describing Gustafson as "a structural approach, 'dynamic' approach, or some unconventional variation of a conventional textual approach" and as "a drastic departure from the Court's consistently literal plain meaning approach in construing the federal securities laws").

106. 521 U.S. 642 (1997).

107. See, e.g., Walker \& Levine, supra note 27, at 5 (describing O'Hagan decision as a retreat from the textual analysis of Central Bank); Fahey, supra note 92, at 530 (arguing that O'Hagan decision was based on purposivism, not textualism).

108. See O'Hagan, 521 U.S. at 664 ("Central Bank's discussion concerned only private civil litigation under $\S 10(\mathrm{~b})$ and Rule 10b-5, not criminal liability."). The O'Hagan decision's quote from page 173 of the Central Bank decision is telling: "We have refused to allow [private] 10b-5 challenges to conduct not prohibited by the text of the statute." Id. at 651 . The O'Hagan Court inserts the word "private."

109. Id.

110. See, e.g., Walker \& Levine, supra note 27 , at 21 . Walker and Levine argue that O'Hagan confirms that Central Bank has not ushered in the revolution in the interpretation of the securities laws that some have proclaimed. The mere fact that a specific fraudulent practice, such as insider trading, is not literally prohibited by the text of section 10 (b) does not mean, under Central Bank, that 


\section{B. Legislative Ratification or Acquiescence}

Even if the lower courts reject a strong textualist approach, they may nonetheless be reluctant to rely heavily on the recent legislation in interpreting the scope of outside professional liability. The Supreme Court has repeatedly refused to consider subsequent legislative developments in interpreting the scope of a statute. ${ }^{111}$ Indeed, in Central Bank, the Court explicitly rejected the argument that Congress's adoption of several amendments to the federal securities laws after courts widely interpreted section 10 (b) to provide a cause of action for aiding and abetting securities fraud was evidence that Congress acquiesced in these interpretations. ${ }^{112}$

Commentators typically proffer two bases upon which to consider subsequent legislation: ratification and acquiescence. Ratification requires affirmative action by Congress. This action can arguably range from Congress reenacting the statute in question and explicitly adopting the courts' interpretation, to Congress adopting a subsequent statute that builds upon the structure established by the interpretation, to a congressional vote that defeats a proposed amendment to overturn the interpretation. ${ }^{113}$ The strongest argument in favor of ratification characterizes Congress's action as an adoption of the courts' interpretation of the statute and an incorporation of that interpretation into law. The counterargument is that, for this adoption to have the effect of lawmaking, it can only be achieved through the formal legislative process.

It is more difficult to justify reliance on congressional acquiescence as a basis for referencing subsequent legislation because it is, in effect, reliance on congressional silence or inaction. The argument is that when Congress amends a statute that has been previously interpreted by the courts without revising the statute to modify the courts' interpretation, the amendment constitutes implicit approval of those aspects of the interpretation that have not been changed. As the Court and commentators have observed, the vagaries of the legislative process make it difficult to ascertain the causes of congressional inaction. This makes it hazardous to use inaction as an indication of congressional intent. ${ }^{114}$

the practice does not violate section 10(b)'s broad prohibition against manipulative or deceptive devices or contrivances. Id.

111. See, e.g., Pub. Employees Retirement Sys. of Ohio v. Betts, 492 U.S. 158, 168 (1989) ("We have observed on more than one occasion that the interpretation given by one Congress (or a committee or Member thereof) to an earlier statute is of little assistance in discerning the meaning of that statute.").

112. See supra notes $36-38$ and accompanying text.

113. See, e.g., Donald R. Livingston \& Samuel A. Marcosson, The Court at the Crossroads: Runyon, Section 1981 and the Meaning of Precedent, 37 Emory L.J. 949, 970 (1988).

114. “Congress's failure to overturn a statutory precedent is [not] reason for this Court to adhere to it. It is 'impossible to assert with any degree of assurance that congressional failure to act represents' affirmative congressional approval of the Court's 
There is a difference, however, between using congressional ratification or acquiescence as a basis for adhering to a prior judicial interpretation of a statute and looking to subsequent legislation for interpretive guidance. ${ }^{115}$ This is particularly true when, as in the present case, the subsequent legislation both provides affirmative evidence of the congressional objectives behind the regulatory scheme and reconfigures that scheme in light of problems that had previously been identified by the Court. It is possible to argue-as the Court does, particularly when it employs strict textualism-that the intent of the current Congress is irrelevant to the question of how to interpret a statute passed a number of years ago. ${ }^{116}$ Still, the separation of powers principles that support textualism also counsel deference to the legislature to resolve policy issues. Accordingly, when a Court is engaged in policy analysis, it seems appropriate to consider the articulated position of Congress on the policy question involved.

Additionally, this approach provides a basis for employing the principles behind dynamic statutory interpretation, ${ }^{117}$ yet it grounds those principles within the constitutional structure. The Court may find it appropriate to consider recent developments in interpreting a statute, but be concerned about charges of activism if it relies upon its judgment to make policy choices. Reference to subsequent congressional intent with regard to the relevant policy issues allows the Court to combine legislative deference with a realistic approach to the issues at hand. In an area such as securities regulation, where Congress has broadly delegated lawmaking authority to the courts, judicial consideration of recent legislation reconfigures the lawmaking process as more of a partnership.

\section{Future Direction on Liability Standards-A Travel Advisory FOr THE Federal Courts}

As indicated above, reliance on the methodology of strict textualism offers little guidance for lower courts in articulating a standard of primary liability for secondary defendants. If, however, decisions such as O'Hagan can properly be read as modifying the Central Bank approach, lower

statutory interpretation." Patterson v. McLean Credit Union, 109 S. Ct. 2363, 2371 n.1 (1989) (quoting Johnson v. Transportation Agency, 480 U.S. 616, 671-72 (1987) (Scalia, J., dissenting)). See also John C. Grabow, Congressional Silence and the Search for Legislative Intent: A Venture Into "Speculative Unrealities," 64 B.U. L. Rev. 737, 746-48 (1985) (explaining why it is inappropriate to rely on congressional silence or inaction as probative of congressional intent).

115. Cf. Thel, supra note 97, at 1093-94 (arguing that Court's analysis of the misappropriation theory of insider trading should be influenced by statutory "findings" contained in the Insider Trading and Securities Fraud Enforcement Act of 1988).

116. Cf. id. at 1122 (evaluating power of Congress to decide in 1988 what it intended in an earlier statute).

117. See generally Eskridge, supra note 100 (advocating a methodology in which statutes are interpreted in light of post-enactment developments and current societal context). 
courts should be looking beyond the statutory text to answer the question. This Article advocates that courts look to the Reform Act and the Uniform Standards Act for clarification of congressional intent. Courts should then formulate a liability standard consistent with the congressional purpose behind imposing liability on securities professionals and the policy considerations relevant to that objective.

O'Hagan explicitly affirms the relevance of the purposes of a statute to its interpretation. In accepting the misappropriation theory, the Court explained, "The theory is also well-tuned to an animating purpose of the Exchange Act: to insure honest securities markets and thereby promote investor confidence." 18 Similarly, the Court indicated in Virginia Bankshares, Inc. v. Sandberg that "where a legal structure of private statutory rights has developed without clear indications of congressional intent, the contours of that structure need not be frozen ...." and that, in such a case, it is appropriate to look to policy reasons for deciding where the "outer limits" of the cause of action should lie. ${ }^{119}$ In light of O'Hagan's characterization of Central Bank as predicated upon policy considerations, subsequent courts should use these policy considerations to inform their interpretation of Central Bank, and hence the scope of primary liability.

The policy issue that concerned the Central Bank Court was the risk of abusive litigation. ${ }^{120}$ The Court found that section $10(\mathrm{~b})$ presented a particular risk of excessive and vexatious litigation, and the Court identified a specific problem in the imposition of 10 (b) liability upon secondary actors. ${ }^{121}$ Outside professionals, the Court feared, were required to expend large sums in defense even in cases in which their involvement in the transaction was minimal. ${ }^{122}$ Moreover, the Court warned that the litigation costs incurred by these outside professionals could be passed on to clients. ${ }^{123}$

These observations are clearly relevant in formulating a liability standard for secondary defendants. Yet, the litigation structure that led to the concerns identified in Central Bank has been significantly altered by subsequent legislative reform. At first blush, the tenor of the subsequent legislation seems to support the argument that the scope of liability for secondary defendants should be drawn narrowly. As the Central Bank Court observed, an expansive liability standard would subject outside professionals to more extensive litigation. ${ }^{124}$ The Court viewed this exposure as undesirable. ${ }^{125}$ Both the Reform Act and the Uniform Standards Act indicate a similar congressional mindset; the statutes demonstrate the de-

118. United States v. O’Hagan, 521 U.S. 642, 654 (1997).

119. 501 U.S. 1083, 1104-05 (1991).

120. See Central Bank of Denver v. First Interstate, 511 U.S. 164, 189 (1994).

121. See id.

122. See id.

123. See id.

124. See id.

125. See id. 
sire to reduce the scope of private securities fraud litigation generally and the exposure of collateral defendants in particular. Additionally, Congress seems to have concurred in the Central Bank result by its explicit refusal to reverse the Central Bank decision and thereby reinstate aiding and abetting liability in private litigation.

Upon further analysis, however, the significance of the subsequent legislation appears more ambiguous. Although Congress refused to restore aiding and abetting liability, it clearly anticipated the continued liability of secondary defendants when it adopted the Reform Act provision establishing proportionate liability. Proportionate liability rules are of limited importance unless the general standard of liability holds collateral defendants responsible for securities fraud. ${ }^{126}$ Moreover, the Reform Act goes further with respect to accountants by imposing on them an affirmative obligation to report their clients' wrongdoing. ${ }^{127}$ By establishing this whistleblowing obligation, Congress directly rejected the position of courts that held, even pre-Central Bank, that silence or inaction was an insufficient basis for the imposition of liability upon secondary defendants. ${ }^{128}$

The significance of the Reform Act extends beyond the provisions that deal explicitly with secondary defendants. Indeed, the primary objective of the Reform Act-reduction of vexatious litigation-is the aspect of the Act most relevant to determining the standards of liability for outside professionals. As indicated above, Central Bank was motivated by the belief that securities litigation posed a particular risk to secondary defendants of vexatious litigation, and that such litigation caused undesirable pressure to settle frivolous cases and imposed socially undesirable costs upon professionals that might ultimately be borne by their clients. ${ }^{129}$ This same concern was Congress's rationale for adopting the Reform Act. ${ }^{130}$ If, however, the Reform Act effectively reformed private securities litigation to reduce or eliminate the problem of vexatious litigation, the adoption of the Reform Act may have removed the justification proffered in Central Bank for narrowing the scope of secondary de-

126. See, e.g., Donald C. Langevoort, Capping Damages for Open Market Securities Fraud, 38 Ariz. L. Rev. 639, 640 (1996) (describing proportionate liability as "a centerpiece proposal for reform, but largely as a mechanism for benefiting the collateral participant (usually accountants and lawyers)").

127. See Private Securities Litigation Reform Act of $1995 \S 301$, Pub. L. No. 104-67, 109 Stat. 737, 762-64 (adding $\S 10$ A to the Securities Exchange Act of 1934, 15 U.S.C. $\S 78 a)$.

128. Cf. Jeanne Calderon \& Rachel Kowal, Auditors Whistle an Unhappy Tune, 75 Denv. U. L. Rev. 419, 430-31 (1998) (arguing that Reform Act's creation of new disclosure obligations for accountants may impose sufficient duty to impose liability for failure to blow the whistle on client fraud).

129. See Central Bank, 511 U.S. at 189.

130. See Harrison, supra note 71 , at 533 . 
fendant liability. ${ }^{131}$ In other words, the policy rationale for Central Bank may no longer justify the result.

This possibility is particularly important because the Central Bank decision itself recognized that choosing an appropriate liability rule creates a tension between two competing objectives: protecting the ability of outside professionals to serve their clients and protecting investors. As the Central Bank Court noted, expansive liability for securities professionals raises concerns about abusive litigation, and the costs and settlement pressures associated with such litigation. ${ }^{132}$ These costs may be passed on to the client and may ultimately prevent some clients from obtaining the benefit of professional services. Without the assistance of outside professionals to explain disclosure requirements, formulate appropriate language, review documentation for consistency with industry standards, and so forth, issuers would be less able to meet the regulatory disclosure standards. In addition, the risk of litigation may cause outside professionals to perform their services in a way that minimizes their liability exposure at the expense of more complete service to the client. It is necessary for outside professionals to become intimately involved in the disclosure process in order to serve their clients effectively. A liability rule that encourages professionals to limit their participation in preparing client disclosure may therefore undercut the disclosure process. ${ }^{133}$ These problems can directly undermine the objective of federal securities regulation: full and fair disclosure of all material information. ${ }^{134}$

At the same time, the securities disclosure system is premised upon the supposition that outside professionals will be involved in the disclosure process. The statutory scheme relies, in part, on this involvement as a substitute for greater supervision by government regulators. ${ }^{135}$ Investors also view the involvement of reputable professionals as a signal that the issuer's disclosure is reliable. ${ }^{136}$ Outside professionals thus function as gatekeepers who prevent improper transactions from obtaining the appearance of regularity necessary to attract investment funds. This structure may be efficient in that outside professionals may be more readily

131. Indeed, the advent of legislative reform may remove the justification for the Supreme Court's general use of textualism to narrow the scope of private securities litigation.

132. See Central Bank, 511 U.S. at 189.

133. See City Bar Amicus Brief in Klein, supra note 64, at 13-14 (explaining that inappropriate liability standard could interfere with the effectiveness of the disclosure process).

134. See, e.g., Landreth Timber Co. v. Landreth, 471 U.S. 681, 687 (1985) (describing Congress's remedial purpose of providing full and fair disclosure in enacting the federal securities laws).

135. See, e.g., City Bar Amicus Brief in Central Bank, supra note 25 (describing gatekeeping role of outside professionals in assuring proper functioning of federal securities laws and investor reliance upon that role).

136. See, e.g., Warren, supra note 51 , at 386 ("[I]t is the securities lawyer who controls the disclosure process and who undertakes to align the interests of the client issuer with the client's investors."). 
able to access client information than regulators. Lax liability standards interfere with the incentive of professionals to perform this gatekeeping function by allowing professionals to sacrifice investor protection in favor of maintaining a relationship with unscrupulous clients.

Although the Court in Central Bank left open the door with respect to liability of outside professionals, the decision demonstrated a judicial inability or unwillingness to attempt to balance these policy concerns. In formulating a rule of primary liability for secondary defendants, lower courts may be able to address this omission and to effect a compromise between the two competing goals. With the advent of legislative reform, the courts' task is simplified. To the extent that the Reform Act has reduced the exposure of outside professionals to vexatious litigation, ${ }^{137}$ courts have the leeway to adopt a liability rule that places greater emphasis on the gatekeeping function without subjecting professionals to excessive litigation risk.

Moreover, the structure of the Reform Act suggests that Congress intended for the courts to perform this function. Rather than specify the circumstances under which outside professionals should be liable in private litigation, Congress adopted a framework under which the courts are required to make this determination on a case-by-case basis. Accordingly, although Congress has endorsed liability for secondary defendants, the Reform Act leaves for the courts the job of fine-tuning such liability consistent with the statutory goals that place primary importance on full and fair disclosure ${ }^{138}$ and the protection of investors. ${ }^{139}$

The recent adoption of the Uniform Standards Act lends additional support to this position. Although the Reform Act reduced the liability exposure of secondary defendants under federal law, it was still possible for plaintiffs to bring state court actions based upon state blue sky laws or common law fraud. Many states applied generous liability rules to joint tortfeasors that could undercut the protection of the proportionate liability provision. ${ }^{14}$ Indeed, immediately after the adoption of the Reform Act, plaintiffs filed a number of securities fraud suits in state court, pre-

137. Early analyses suggest that the Reform Act is effectively achieving this result. For example, the SEC's preliminary post-Reform Act statistics revealed a dramatic decline in the number of outside professionals named as defendants in securities fraud litigation. See Richard H. Walker et al., The New Securities Class Action: Federal Obstacles, State Detours, 39 Ariz. L. Rev. 641, 651 (1997) (describing statistical differences in suits filed against accountants, attorneys, and underwriters before and after the Reform Act).

138. See, e.g., Santa Fe Industries, Inc. v. Green, 430 U.S. 462, 477-78 (1977) (primary purpose of federal securities laws is to implement "a philosophy of full disclosure").

139. See, e.g., SEC v. Capital Gains Research Bureau, Inc., 375 U.S. 180, 186 (1963) (holding that one of the principal purposes of federal securities regulation is protection of investors).

140. See, e.g., Thomas W. Antonucci, The Private Securities Litigation Reform Act and the States: Who Will Decide the Future of Securities Litigation?, 46 Emory L.J. 1237, 1253-54 (1997) (describing how state law, which generally provides for joint and several liability, allows plaintiffs to avoid the proportionate liability limitation of the Reform Act) 
sumably for the purpose of exploring the extent to which state courts and state law offered a viable substitute for federal securities litigation. ${ }^{141}$ These suits did not appear, however, to be efforts to circumvent the proportionate liability provision of the Act. ${ }^{142}$

The Uniform Standards Act effectively eliminates this substitute litigation. By providing exclusive federal court jurisdiction for all private class action litigation arising from fraudulent securities transactions, the Act secures the previously adopted litigation reforms for secondary defendants in virtually all cases involving large scale damage claims. Thus, the Uniform Standards Act supplements the Reform Act in providing more complete application of the provisions aimed at reducing vexatious litigation. At the same time, the Uniform Standards Act ensures that the federal courts will be the ultimate authority on the circumstances under which it is appropriate to hold secondary defendants accountable. ${ }^{143}$

As a consequence of the recent legislation, courts that currently are faced with the question of how to determine the scope of liability for outside professionals have information available beyond the original text of section 10 (b) to assist them in that task. Congress has explicitly stated that it is appropriate to impose liability on lawyers, accountants, and investment banks, and that such liability is consistent with the purposes of the statute. Indeed, Congress has affirmed the propriety of imposing such liability within the context of private civil litigation. The recent legislation indicates congressional desire to have outside professionals serve a gatekeeping role in the securities industry. Appropriate liability rules further that objective. Finally, the legislative structure authorizes the

141. See, e.g., Michael A. Perino, Fraud and Federalism: Preempting Private State Securities Fraud Causes of Action, 50 Stan. L. Rev. 273 (1998) (describing various postReform Act empirical studies measuring increase in state court securities litigation and explaining how state court suits could allow plaintiffs to avoid some of the reforms adopted by the Reform Act).

142. See Walker, supra note 137, at 678 (observing that initial state court suits filed after the Reform Act did not seem to be aimed at "peripheral deep pocket defendants").

143. A distinct component of the Uniform Standards Act further supports reading it as a congressional affirmation of broad judicial lawmaking authority. The Reform Act raised some question about whether Congress intended to change the judicially developed standard for establishing scienter under section 10 (b). See Robert A. Prentice, The Future of Corporate Disclosure: The Internet, Securities Fraud, and Rule 10b-5, 47 Emory L.J. 1, 50-51 (1998) (discussing judicial disagreement over whether Reform Act eliminated liability for reckless conduct). In response to concerns expressed by the SEC, Congress expressly stated in the legislative history of the Uniform Standards Act that it did not intend to change the recklessness standard. See The Securities Litigation Uniform Standards Act of 1988, S. Rep. No. 105-182, at 4 (1998) ("[T] Committee emphasizes that the clear intent in 1995 and our continuing intent in this legislation is that neither PSLRA nor S. 1260 in any way alters the scienter standard in federal securities fraud suits."); Rachel Witmer, Litigation Reform: SEC Throws Weight Behind Reform Bill, 30 Sec. Reg. \& L. Rep. (BNA) 477 (1998) (describing congressional response to SEC's concerns). Notably, rather than adopting its own substantive standard, Congress again expressed its approval of the standard crafted by the federal courts. 
courts to develop those liability rules and, in so doing, to consider the objectives and policies inherent in federal securities regulation.

Acknowledging the significance of the recent legislation does not free the lower courts from hard choices. It does, however, suggest that some lower courts such as the Second Circuit in Wright are taking an unnecessarily restrictive approach by requiring that a defendant actually make a fraudulent statement in order to incur primary liability. Even decisions like Klein, which rely on a broad conception of who is a speaker, may have been unduly constrained by the effort to limit primary liability to defendants who are the speakers or authors of misleading statements. Such a liability rule does not recognize the substantial and important role played by securities professionals in the preparation of disclosure documents. Nor does it take cognizance of the importance of encouraging a close and candid relationship between the professional and his client. Finally, the liability rule fails to consider the importance of securities professionals as gatekeepers and effectively allows unscrupulous professionals to insulate themselves from liability at the expense of investor protection. As future courts struggle to answer the questions left unresolved by Central Bank, the foregoing policies should enable them to formulate a standard more faithful to the statutory purposes.

This conclusion is strikingly consistent with William Cary's vision of the appropriate role for the federal courts in interpreting the federal securities laws. Decisions written by Cary on behalf of the SEC, such as the Cady, Roberts decision, ${ }^{144}$ as well as the SEC's advocacy position in cases like Borak, ${ }^{145}$ illustrate Cary's view that the federal courts should interpret the federal securities laws broadly to further the remedial goals of investor and market protection. Cary's legacy continues to be felt, as the federal courts have become entrenched in the role of developing the federal securities laws and, in many cases, have accepted Cary's ideas about the appropriate statutory goals. Cary's legacy gave federal securities regulation a structure that maintains a delicate balance between investor protection and excessive liability exposure. Recent legislation demonstrates a congressional commitment, in large part, to the contours of that balance, and to the preservation of the regulatory structure envisioned by Cary. To the extent that Central Bank's textualist approach argues against this structure, it threatens the fundamental policy objectives of the securities laws.

\section{Conclusion}

Although the Court has never formally repudiated its decision in J.1. Case v. Borak, since that time it has retreated from the general approach espoused by William Cary, both by reducing its willingness to recognize implied private rights of action and by rejecting its formerly expansive 
remedial interpretation of the federal securities laws in favor of greater adherence to the statutory text. The Court's strict textualist approach reached a peak in the Central Bank decision, in which the Court concluded that the statute failed to provide a private right of action against those who aid and abet securities fraud.

The Central Bank Court left to lower courts the task of developing standards for when secondary defendants could nonetheless be held liable as primary violators, and the challenge of formulating such standards within the parameters of the Central Bank decision. Although Central Bank seemed to direct courts to take a narrow approach, subsequent Supreme Court decisions and, more importantly, recent legislation suggest a return to the remedial principles espoused by Chairman Cary. The adoption of the Private Securities Litigation Reform Act of 1995 and the Uniform Standards Act of 1998 should be read as explicit congressional endorsements of private securities litigation. Moreover, the recent legislation clearly demonstrates Congress's recognition that, despite some problems that can be addressed through legislative reform, private litigation, including claims of private civil liability of secondary defendants, remains an important tool for deterring fraud and protecting investors in the U.S. securities markets. In addressing the scope of liability for secondary defendants, the courts should not sacrifice these concerns in favor of rigid adherence to the statutory text. 